\title{
MICROPROPAGATION OF YARDLONG BEAN (VIGNA UNGUICULATA (L.) WALSP. SSP. SESQUIPEDALIS L. VERDC.) THROUGH IN VITRO CULTURE
}

\author{
I Jahan*，N Alam and PK Roy ${ }^{1}$ \\ Department of Botany, Jahangirnagar University, Savar, Dhaka-1342, Bangladesh
}

Key words: Multiple shoots, Acclimation, Regeneration, Vigna unguiculata ssp. sesquipedalis

\begin{abstract}
An in vitro propagation protocol has been established for yardlong bean (Vigna unguiculata ssp. sesquipedalis L. Walp. Verdc.) using shoot tip, nodal and leaf segment explants of the superior plant type obtained from crossing of two selected parental lines. Explants were cultured on MS medium supplemented with different concentrations and combinations of BAP, Kn and Zeatin and NAA, IAA, IBA. The highest percentage (86) of shoot regeneration with maximum shoots per culture $(12 \pm 0.43)$ was obtained from nodal explants on MS medium supplemented with $0.5 \mathrm{mg} / \mathrm{l} \mathrm{BAP}$ and $0.2 \mathrm{mg} / \mathrm{l} \mathrm{NAA}$. Addition of $10 \%$ coconut water and $75 \mathrm{mg} / \mathrm{l}$ urea to the medium enhanced shoot multiplication and elongation, respectively. Rooting of the regenerated shoots was optimum on half-strength MS enriched with $3.0 \mathrm{mg} / \mathrm{l} \mathrm{IBA}$. Regenerated plantlets were successfully acclimatized. After acclimation, plantlets were transplanted in the experimental field where the survival rate was $80 \%$.
\end{abstract}

Yardlong bean (Vigna unguiculata ssp. sesquipedalis L. Walp. Verdc., Fabaceae) is a popular legume vegetable of Bangladesh which contributes substantially to vegetables supply and constitutes an important source of proteins in daily diet.

Considering the nutritional values and public demand, the cultivation of this vegetable crop is being emphasized throughout the country. The major threats of yardlong bean cultivation are insects, mites and nematodes as well as viral, bacterial and fungal attacks.

Micropropagation of a superior disease free yardlong bean variety or development of a disease resistant variety can solve this problem. Two selected parental lines of yardlong bean were crossed (Kashem king $\times$ Hazari’s Lal Borboti). A superior $F_{1}$ was obtained and hence a suitable in vitro micropropgation was developed in order to maintain the characteristics of this superior $F_{1}$ in the next progenies.

Shoot tips, nodal segments and young leaves were collected from improved $F_{1}$ of $V$. unguiculata ssp. sesquipedalis grown in the experimental field, Institute of Food and Radiation Biology, Atomic Energy Research Establishment, Savar, Dhaka and were used as explants in micropropagation. These plant materials were washed thoroughly with running tap water for 25 minutes. Surface sterilization was done by rinsing the plant materials with $0.1 \% \mathrm{HgCl}_{2}$ for six minutes followed by washing repeatedly ( 7 - 8 times) with autoclaved distilled water. All these procedures were performed under aseptic conditions in a laminar air flow cabinet. Before implanting on to the culture media they were cut into appropriate sizes (approx. $1.0-1.5 \mathrm{~cm}$ in length) for explants. MS medium was used for regeneration of complete plantlets through in vitro culture. Explants were cultured on MS supplemented with different concentrations of BAP, Kn, zeatin and NAA, IBA, IAA either singly or in combination for shoot regeneration. Media supplements such as coconut water $(\mathrm{CW})$ and urea were added to the medium for the determination of their effects on shoot multiplication and elongation, respectively. The $\mathrm{pH}$ of the

\footnotetext{
*Author for correspondence: < isratjahan_ju@yahoo.com >. ${ }^{1}$ Institute of Food and Radiation Biology, Atomic Energy Research Establishment, Savar, Dhaka-1000, Bangladesh.
} 
media was adjusted to 5.8 before adding agar. All media were gelled with $0.7 \%$ agar. The cultures were maintained at $25 \pm 2^{0} \mathrm{C}$ under cool white fluorescent light for a daily 16 hrs photoperiod with light intensity of 3000 lux. Subculturing was done every three weeks interval. Half-strength MS supplemented with IBA, IAA and NAA were used for root induction.

Observations were made after four weeks of culture. For hardening, rooted shoots were taken out from the test tubes, gently washed to free the medium from roots. They were transferred to poly bags containing a mixture of sterile soil, sand and compost $(2: 1: 1)$ and covered with poly bag. The plantlets were exposed to high humidity and diffuse sunlight for 7 days for hardening. After 15 - 20 days, the plantlets were planted in the experimental field.

A high frequency of shoot regeneration was obtained when shoot tips, nodal and leaf segment explants were cultured onto MS medium supplemented with diverse concentrations and combinations of growth regulators. MS supplemented with $0.5 \mathrm{mg} / \mathrm{l}$ BAP and $0.2 \mathrm{mg} / \mathrm{l} \mathrm{NAA}$ proved as the most conducive medium for shoot tip and nodal segment derived direct shoot regeneration and multiplication (Table 1). The shoot tip and nodal explants showed positive response in the same media combinations. Leaf segments also comprised an important explant for direct multiple shoot development (Table 2). Some reports are

Table 1. Effects of different concentrations and combinations of various growth regulators on shoot proliferation from shoot tip and nodal segments.

\begin{tabular}{|c|c|c|c|c|c|c|c|}
\hline \multirow{3}{*}{$\begin{array}{l}\text { Media } \\
\text { combinations } \\
(\mathrm{mg} / \mathrm{l})\end{array}$} & \multicolumn{7}{|c|}{ Explants } \\
\hline & \multicolumn{4}{|c|}{ Shoot tips } & \multicolumn{3}{|c|}{ Nodal segments } \\
\hline & $\begin{array}{l}\text { No. of } \\
\text { replicates/ } \\
\text { treatments }\end{array}$ & $\begin{array}{c}\text { \% of } \\
\text { explants } \\
\text { producing } \\
\text { shoots }\end{array}$ & $\begin{array}{l}\text { Mean no. of } \\
\text { shoots/ } \\
\text { culture } \\
\pm \text { SE }\end{array}$ & $\begin{array}{c}\text { Average } \\
\text { shoot length } \\
(\mathrm{cm}) \pm \mathrm{SE}\end{array}$ & $\begin{array}{l}\% \text { of } \\
\text { explants } \\
\text { producing } \\
\text { shoots }\end{array}$ & $\begin{array}{l}\text { Mean no. of } \\
\text { shoots/ } \\
\text { culture } \pm \text { SE }\end{array}$ & $\begin{array}{c}\text { Average } \\
\text { shoot length } \\
(\mathrm{cm}) \pm \mathrm{SE}\end{array}$ \\
\hline $\operatorname{BAP}(0.5)$ & 50 & 82 & $6.1 \pm 0.34$ & $5.9 \pm 0.18$ & 84 & $10.6 \pm 1.25$ & $6.8 \pm 0.12$ \\
\hline $\mathrm{BAP}+\mathrm{NAA}(0.5+0.2)$ & 50 & 84 & $8.2 \pm 0.17$ & $6.5 \pm 0.21$ & 86 & $12.3 \pm 0.43$ & $6.9 \pm 0.32$ \\
\hline $\mathrm{BAP}+\mathrm{IAA}(0.5+0.2)$ & 50 & 72 & $5.1 \pm 0.17$ & $5.9 \pm 0.21$ & 58 & $9.6 \pm 1.18$ & $5.25 \pm 0.25$ \\
\hline $\mathrm{Kn}(1.5)$ & 50 & 46 & $4.1 \pm 0.26$ & $3.3 \pm 0.23$ & 52 & $5.2 \pm 1.23$ & $3.2 \pm 0.15$ \\
\hline $\mathrm{Kn}+\mathrm{NAA}(1.0+0.2)$ & 50 & 54 & $4.1 \pm 0.29$ & $3.1 \pm 0.56$ & 66 & $6.1 \pm 0.14$ & $3.6 \pm 0.18$ \\
\hline $\mathrm{Kin}+\mathrm{IAA}(1.0+0.2)$ & 50 & 50 & $5.3 \pm 0.12$ & $3.4 \pm 0.18$ & 56 & $5.1 \pm 0.12$ & $3.7 \pm 0.18$ \\
\hline Zeatin + NAA $(1.0+0.2$ & 50 & 78 & $5.3 \pm 0.51$ & $6.2 \pm 0.34$ & 80 & $11.2 \pm 0.64$ & $6.3 \pm 0.85$ \\
\hline $2 \mathrm{iP}+\mathrm{NAA}(1.0+0.2)$ & 50 & 58 & $5.2 \pm 0.24$ & $3.7 \pm 0.65$ & 60 & $6.2 \pm 1.38$ & $3.1 \pm 0.62$ \\
\hline
\end{tabular}

$\mathrm{SE}=$ Standard error

found regarding in vitro regeneration of $V$. unguiculata which describes the use of primary leaves (Muthukumar et al. 1995, Ramkrishnan et al. 2005) and shoot tips (Kartha et al. 1981, Brar et al. 1997a, Mao et al. 2006) as explants of choice. Brar et al. (1997b) cultured shoot tips on MS medium augmented with $5.0 \mathrm{mg} / \mathrm{l} \mathrm{Kn}$ and $0.01 \mathrm{mg} / \mathrm{l} \mathrm{NAA}$. Multiple shoots were produced from shoot tips, and these grew well when cultured on full strength MS. Aasim et al. (2008) produced multiple shoots from shoot meristems of three - five-day-old in vitro grown seedlings of Turkish cowpea (V. unguiculata L.) cv. akkiz on MS supplemented with $0.5 \mathrm{mg} / \mathrm{l} \mathrm{BAP}$ and $0.5 \mathrm{mg} / \mathrm{l} \mathrm{NAA}$. In the present investigation, $86 \%$ nodal explants produced shoots, mean number of shoots per explant was $12.3 \pm 0.43$ with an average length of $6.9 \pm 0.32 \mathrm{~cm}$ on MS medium supplemented with $0.5 \mathrm{mg} / \mathrm{l} \mathrm{BAP}$ and $0.2 \mathrm{mg} / \mathrm{l} \mathrm{NAA} \mathrm{(Table} \mathrm{1,} \mathrm{Fig.} \mathrm{1a).} \mathrm{In} \mathrm{the} \mathrm{same} \mathrm{medium,} \mathrm{average} 8.2 \pm 0.17$ shoots proliferated per shoot tip explants (Table 1, Fig. 1b). In leaf segment explants, the highest percentage (64) of shoot regeneration was observed on MS supplemented with $1.0 \mathrm{mg} / \mathrm{l}$ zeatin and 
0.2 mg/l NAA (Table 2, Fig. 1c). Brar et al. (1997b) cultured leaf disks of $V$. unguiculata L. on MS media supplemented with $0.5 \mathrm{mg} / \mathrm{l} \mathrm{BAP}$ and $1 \mathrm{mg} / \mathrm{l} 2$, 4-D for shoot regeneration and found satisfactory results.

Table 2. Influences of different concentrations and combinations of various growth regulators on shoot regeneration from leaf explants.

\begin{tabular}{lcccc}
\hline $\begin{array}{l}\text { Media combinations } \\
(\mathrm{mg} / \mathrm{l})\end{array}$ & $\begin{array}{c}\text { No. of } \\
\text { replicates/ } \\
\text { treatments }\end{array}$ & $\begin{array}{c}\text { \% of explants } \\
\text { producing } \\
\text { shoots }\end{array}$ & $\begin{array}{c}\text { Mean no. of } \\
\text { shoots/ } \\
\text { culture } \pm \text { SE }\end{array}$ & $\begin{array}{c}\text { Average shoot } \\
\text { length (cm) } \\
\pm \text { SE }\end{array}$ \\
\hline BAP (1.5) & 25 & 20 & $4.6 \pm 0.26$ & $1.8 \pm 0.31$ \\
BAP + NAA $(1.0+0.1)$ & 20 & 45 & $4.3 \pm 0.50$ & $1.9 \pm 0.12$ \\
BAP + IAA $(0.5+0.1)$ & 50 & 42 & $4.2 \pm 0.37$ & $2.5 \pm 0.28$ \\
Kn (1.0) & 50 & 26 & $3.1 \pm 0.15$ & $2.6 \pm 0.15$ \\
Kn + NAA $(1.0+0.2)$ & 25 & 32 & $4.1 \pm 0.12$ & $2.8 \pm 0.35$ \\
Kn + IBA (1.5 + 0.2) & 50 & 30 & $4.1 \pm 0.29$ & $3.1 \pm 0.37$ \\
Zeatin (1.5) & 50 & 50 & $5.5 \pm 0.36$ & $3.4 \pm 0.32$ \\
Zeatin + NAA $(1.0+0.2)$ & 25 & 64 & $7.3 \pm 0.23$ & $3.5 \pm 0.48$ \\
2iP + NAA $(1.5+0.2)$ & 50 & 30 & $4.2 \pm 0.83$ & $2.8 \pm 0.45$ \\
\hline
\end{tabular}

$\mathrm{SE}=$ Standard error.
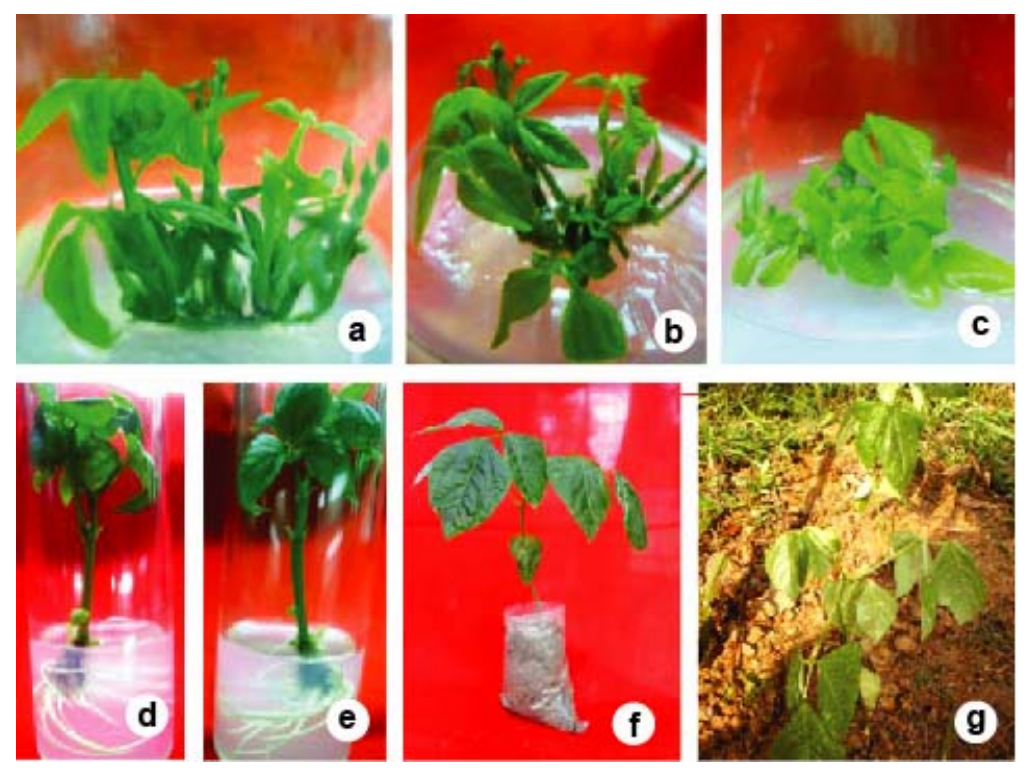

Fig. 1a - g. In vitro regeneration of Vigna unguiculata ssp. sesquipedalis. a - c. Multiple shoot regeneration from nodal segment (a) and shoot tip (b) explants on MS medium supplemented with $0.5 \mathrm{mg} / \mathrm{l} \mathrm{BAP}+$ $0.2 \mathrm{mg} / \mathrm{l} \mathrm{NAA}$ and leaf segment (c) explant on MS supplemented with $1.0 \mathrm{mg} / \mathrm{l}$ zeatin and $0.2 \mathrm{mg} / \mathrm{l}$ NAA. d - e. Root induction on half-strength MS supplemented with $3.0 \mathrm{mg} / \mathrm{l}$ IBA. f. Regenerated plantlets in poly bag containing a mixture of sterile soil, sand and compost (2:1:1). g. Plant in experimental field.

For further development of medium and enhanced shoot proliferation, coconut water, ranging from 5 - 10\% (v/v) was added to the medium before $\mathrm{pH}$ adjustment. Coconut water exerted positive impacts in shoot number proliferation when $10 \%(\mathrm{v} / \mathrm{v})$ was used. In response to $10 \%(\mathrm{v} / \mathrm{v})$ coconut water addition, 17 shoots were proliferated per explant (Fig. 2). Wald et al. (1989) noticed 
coconut water as a beneficial agent which provides a rich source of natural cytokinins. For further elongation of the shoots, urea $(50-250 \mathrm{mg} / \mathrm{l})$ was added simultaneously to the medium and the best response was observed when $75 \mathrm{mg} / \mathrm{l}$ urea was used (Fig. 3). At this concentration, nodal segment derived shoots elongated from $6.9 \pm 0.32$ to $7.4 \pm 0.21 \mathrm{~cm}$.

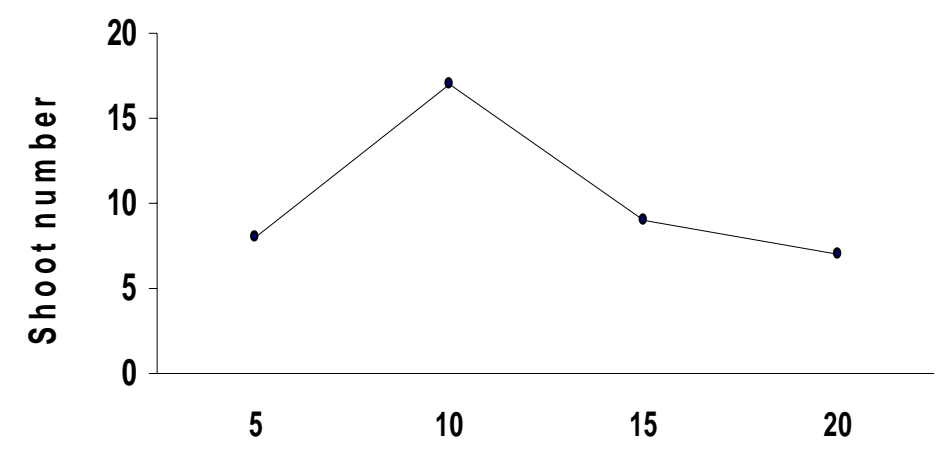

\section{Coconut water $(\%)$}

Fig. 2. Effects of different concentrations of coconut water (5 - 20\%) on shoot multiplication from nodal segment explants.

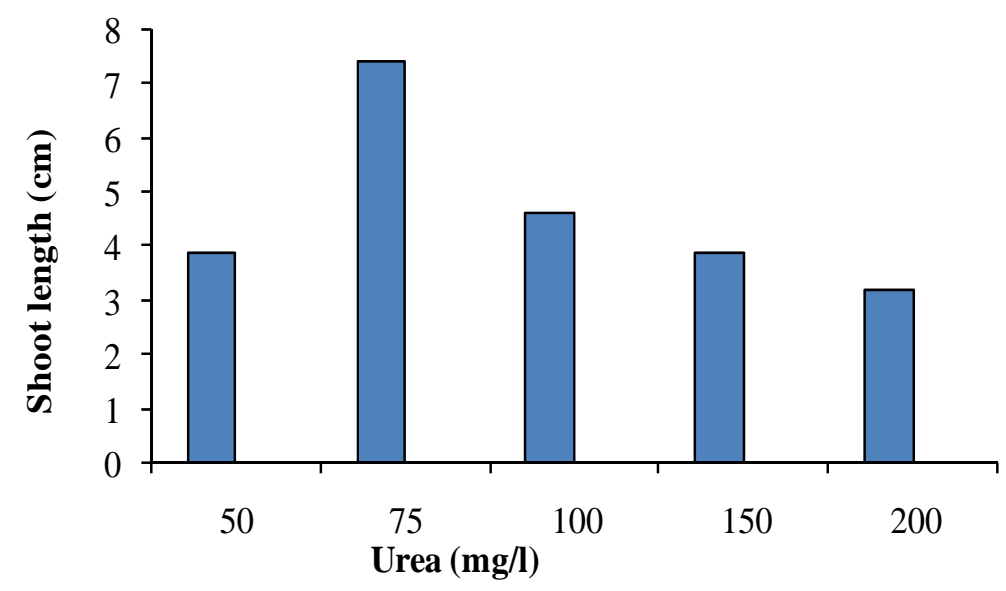

Fig. 3. Effects of different concentrations of urea (50 - 200mg/l) on shoot elongation.

For root induction, in vitro raised well-developed and elongated shoots were excised and cultured on rooting medium containing half-strength MS with different concentrations and combinations of IBA, IAA and NAA. The best result was obtained on half-strength MS supplemented with $3.0 \mathrm{mg} / \mathrm{l}$ IBA (Table 3). In this combination, it was observed that $90 \%$ shoots rooted well within four weeks of culture and each microcutting produced $13.3 \pm 0.64$ roots (Fig. 1d, e)). The superiority of IBA for rooting over other auxins has been reported by many researchers (Caboni and Tonalli 1999, Grewal et al. 1994). 
Table 3. Notable effects of different concentrations of auxins in half-strength MS on root induction of in vitro raised yardlong bean shoots.

\begin{tabular}{llcccc}
\hline $\begin{array}{l}\text { Auxins } \\
(\mathrm{mg} / \mathrm{l})\end{array}$ & (c) & $\begin{array}{c}\text { No. of } \\
\text { replicates/ } \\
\text { treatments }\end{array}$ & $\begin{array}{c}\text { \% of shoots } \\
\text { rooted }\end{array}$ & $\begin{array}{c}\text { Mean no. of roots / } \\
\text { shoot }( \pm \mathrm{SE})\end{array}$ & $\begin{array}{c}\text { Average root length } \\
(\mathrm{cm})( \pm \mathrm{SE})\end{array}$ \\
\hline NAA & 0.5 & 20 & 10 & $3.2 \pm 0.15$ & $1.8 \pm 0.18$ \\
& 1.0 & 25 & 16 & $3.5 \pm 0.32$ & $1.9 \pm 0.33$ \\
IAA & 2.0 & 25 & 8 & $2.6 \pm 0.86$ & $1.9 \pm 0.26$ \\
& 0.5 & 50 & 18 & $4.3 \pm 1.13$ & $2.1 \pm 0.29$ \\
& 1.0 & 50 & 30 & $5.1 \pm 0.85$ & $2.5 \pm 0.41$ \\
IBA & 1.5 & 20 & 20 & $4.2 \pm 0.27$ & $2.3 \pm 0.62$ \\
& 1.0 & 50 & 42 & $4.1 \pm 0.53$ & $3.2 \pm 0.25$ \\
& 2.0 & 25 & 56 & $7.2 \pm 0.14$ & $3.1 \pm 0.37$ \\
& 2.5 & 50 & 68 & $8.7 \pm 0.31$ & $2.5 \pm 0.45$ \\
& 3.0 & 25 & 76 & $13.3 \pm 0.64$ & $3.2 \pm 0.28$ \\
IBA + IAA & $1.0+0.5$ & 25 & 40 & $9.2 \pm 0.48$ & $2.8 \pm 0.56$ \\
& $1.0+1.0$ & 20 & 55 & $4.1 \pm 0.42$ & $2.5 \pm 0.23$ \\
& $2.0+1.0$ & 20 & 45 & $8.2 \pm 0.43$ & $2.7 \pm 0.29$ \\
& $3.0+1.0$ & 25 & 64 & $6.4 \pm 0.32$ & $2.9 \pm 0.31$ \\
& $3.0+2.0$ & 50 & 54 & $9.1 \pm 0.15$ & $3.1 \pm 0.62$ \\
\hline
\end{tabular}

$\mathrm{SE}=$ Standard error.

For acclimatization, plantlets were transferred to poly bags containing a mixture of soil, sand and compost $(2: 1: 1)$. After acclimation, plantlets were subsequently transferred to experimental field (Fig. 1g) where survival rate was $80 \%$. Thus the result of present study will play a positive role for maintaining the purity of an improved yardlong bean line to the next progenies and thus contribute to high yield of this vegetable throughout the country. This work may also be useful for further studies towards the development of desired trait bearing transgenic yardlong bean through Agrobacterium-mediated genetic transformation system.

\section{References}

Aasim M, Khawar KM and Özcan S 2008. In vitro micropropagation from shoot meristems of turkish cowpea (Vigna unguiculata L.) cv. akkiz. Bangladesh J. Bot. 37(2): 149.

Brar MS, Al-Khayri JM, Shamblin CE, McNew RW, Morelock TE and Anderson EJ 1997a. In vitro shoot tip multiplication of cowpea (Vigna unguiculata L. Walp.). In vitro Cell. Dev. Biol. 33: 111-118.

Brar MS, Anderson EJ, Morelock TE and McNew RW 1997b. The effect of media constituents on In vitro culturing of cowpea (Vigna unguiculata L. Walp.) shoot tip and leaf disk explants. J. Arkansas Acad. Sci. 51: 41.

Caboni E and Tonalli MG 1999. Effect of 1,2-Benzisoxazole-3 acetic acid on adventitious shoot regeneration and in vitro rooting in apple. Plant Cell Rep. 18: 985-988.

Grewal HS, Dhatt AS and Gosal SS 1994. Plantlet regeneration from callus in Citrus. Plant Tiss. Cult. 4(1): 9-16.

Kartha KK, Phal K, Leung NL, and Mroginski LA 1981. Plant regeneration from meristems of grain legumes: soybean, cowpea, peanut, chickpea and bean. Can. J. Bot. 59: 1671-1679.

Mao JQ, Zaidi MA, Aranson JT and Altossar I 2006. In vitro regeneration of (Vigna unguiculata L. Walp.) cv. Black eye cowpea via shoot organogenesis. Plant Cell, Tiss. Org. Cult. 87: 121-125.

Muthukumar B, Mariamma M and Gnanam A 1995. Regeneration of plants from primary leaves of cowpea. Plant Cell, Tiss. Org. Cult. 42: 153-155. 
Ramakrishnan K, Gnanam R, Sivakumar P and Manickam A 2005. In vitro somatic embryogenesis from cell suspension cultures of cowpea (Vigna unguiculata L. Walp.). Plant Cell Rep. 24: 449-461

Simpson BB and Ogorzaly MC 2001. Economic Botany; Plants in the World, $3^{\text {rd }}$ edn. p.142.

Wald SG, Litz RE, and Moore GA 1989. Optimizing somatic embryo production in mango. J. Amer.Soc. Hort. Sci. 114: 712-716.

(Manuscript received on 2 July, 2013; revised on 3 September, 2013) 